\title{
THE COMPETITIVENESS CLUSTERS IN CROATIA
}

This study explores the perceptions of members of 13 competitiveness clusters in Croatia (CCC) towards clusters'objectives, processes, setting and performance. Survey data $(n=250)$ were analysed using descriptive statistics, exploratory factor analysis and regression analysis. Results indicate that progress of CCCs is not visible in the observed period and they are lagging behind successful cluster initiatives in the world. The most important reasons for underperformance are related to weaknesses inherited in cluster development framework, poor implementation of activities, inadequate resources for pursuing more ambitious objectives, lack of consensus and weaknesses in strategy formulation. The paper contributes to the literature by evaluating the program of competitiveness clusters for the first time. It examines the factors that contribute to performance of clusters, and compares CCCs with best practices of similar associations in the world. Although this research is based on perceptions of members, it has valuable implications for clusters and policy-makers. In order to strengthen existing clusters, changes in the national framework are needed, while clusters should have more resources at their disposal to reach more ambitious objectives in the future.

Keywords: smart specialisation strategy, cluster competitiveness program, competitiveness clusters, survey, perceptions, early evaluation

* I.-D. Anić, Ph.D., Senior research fellow in permanent position, The Institute of Economics, Zagreb (E-mail: danic@eizg.hr).

${ }^{* *}$ K. Bačić, Ph.D., Independent researcher, scientific associate (E-mail: bacic.keti@ gmail.com).

${ }^{* * *}$ Z. Aralica, Ph.D., Senior research fellow, The Institute of Economics, Zagreb (E-mail: zaralica@eizg.hr).

The paper was received on January 11th, 2018. It was accepted for publication on June 22th, 2018. 


\section{Introduction}

Cluster initiatives (hereafter CIs) have become a popular concept, a policy tool for boosting regional competitiveness and economic growth and an important component in Smart Specialization strategies (Sölvell, Lindqvist and Ketels, 2003; OECD, 2013). In spite of the dispersion of CIs across Europe during the last decade, it is still unclear whether they can be considered successful, and there are open questions of how they can contribute the most in the implementation of Smart Specialization strategies (Sölvell et al., 2003; Lindqvist, Ketels and Sölvell, 2013; European Commission, 2013; Boschma, 2016).

Croatia adopted Smart Specialization strategy (hereafter S3) in 2016, and within this strategy, competitiveness clusters (the concept similar to CIs) are promoted as a policy tool (Croatian Ministry of Economy, entrepreneurship and crafts - MINGO, 2016). Croatian competitiveness clusters (hereafter CCCs) are envisaged as networks of various actors that promote national competitiveness of entire sectors or industries in Croatia.

In past research the concept of clusters has received considerable attention (European Commission, 2013; Zekić and Samaržija, 2017). Previous studies were mostly carried out from the perspective of business clusters, while there are very few studies on CIs, the latter being a rather new phenomenon (Lindqvist et al., 2013). There are studies related to the evaluation of cluster programs and they deal mostly with the questions such as whether cluster programs work and what their impacts are (Maffioli, Pietrobelli and Stucchi, 2016). Although several factors were shown to influence the performance of clusters, there is no definite conclusion on performance drivers. There is a paucity of such research in new EU member states, and, at the same time, there is a need for expanding the understanding of the concept of competitiveness clusters, its development and implementation in an economy.

This study fills the gap in the literature and examines the perceptions of members of CCCs towards objectives, process of cluster development, setting and their performance. The study addresses the following research questions: (1) What is the profile of CCCs?; (2) What is performance of CCCs?, (3) Have CCCs accomplished their goals set for the period? (4) What are the factors that influence CCCs' performance? (5) How are Croatian CCs performing compared to similar associations in the world?

From a broader perspective, this study is an early evaluation of public cluster development program based on perceptions of CCCs' members (most of CCCs were established in 2013). As public programs are expensive, it is necessary to show their effectiveness in an early stage of their development. This is particularly important in countries where competition for public resources is severe and gov- 
ernments are under pressure to discontinue programs that do not show results. For this reason evaluations are sometimes performed early, only a few years after the introduction of the program (Radas and Anic, 2013).

This research is based on the literature dealing with the concept of competitiveness clusters in national policies and Smart specialization strategies, and the assessment of similar cluster associations in the world (Sölvell et al., 2003; Lindqvist et al., 2013). First contribution of this study is to shed more light on a novel and innovative policy approach that consists of introducing CCCs, i.e. networks of economic and public agents engaged in the implementation of Smart specialization strategy. This platform implies that firms, business clusters, public actors, research and academic institutions are working together in a network for the benefit of a sector/industry, and are striving to fulfil the objectives that are aligned with the national S3 objectives. In particular, research results should provide the answer whether CCCs can influence sectoral development and S3 implementation with resources at their hands in Croatia. Second contribution of this paper is in recognising factors that either contribute to or limit CCCs' performance. Final contribution of this paper is in examination whether Croatian clusters are close to "best practices" of similar associations in the world.

The study is expected to have implications to cluster organisations and cluster policy. The findings might help public policy makers revise and adjust the support mechanisms related to $\mathrm{CCCs}$, while the management of competitiveness clusters can use the results to develop more effective strategies.

The paper consists of seven sections. After introduction, the policy concept of competitiveness clusters is presented in the second section, which is followed by the conceptual framework of CCCs in third section. The fourth section contains research methodology, followed by results in fifth section. Section six contains the comparison between CCCs and similar associations in the world. Section seven concludes.

\section{The conceptual framework for assessing competitiveness clusters}

A competitiveness cluster is a concept that is closely related to cluster initiatives (CIs), which is a policy tool for promoting clusters. Model of competitiveness clusters in Croatia resonates with CIs - organised efforts that involve cluster firms, government and/or the research community. While CIs are designed to increase growth and competitiveness of clusters within a region (Sölvell et al., 2003; Ketels, Lindqvist and Sölvell, 2006), CCCs' main goal is to strengthen national industries/ sectors. Despite these differences, analytical framework associated with CIs may 
be employed in the evaluation of CCCs, as CCCs are envisaged as a tool that compensates for the lack of developed clusters. Another argument can be seen in the fact that Croatia is a small economy.

CIs (and in drawing a parallel to CCCs) are often used synonymously with business clusters, and this may lead to confusion (Kowalski and Marcinkowski, 2014). Business cluster is "a geographically proximate group of interconnected companies' suppliers, service providers and associated institutions in a particular field linked by externalities of various types" (Porter 2003, p. 562). CIs offer various services related to cooperation, networking, lobbying, consulting, sharing information, developing websites, contact building, organising training programmes, publishing reports, and relation with media. Their objectives can be related to research, cooperation and networking, policy actions, human resources upgrading, education and training, innovation and technology transfer, cluster expansion, infrastructure building (European Communities, 2008; Lindqvist et al., 2013).

A major problem in the evaluation of cluster programs is related to the measurement of the performance of clusters. Cluster effects can appear short-term, mid-term and long-term. Some effects are related to the overall functioning of the cluster (e.g. services, cooperation, and closing innovation gap), whereas some are more directly linked to cluster firms, such as higher sales, employment, exports, innovation and its sustainability. The main purpose of cluster programs is to achieve desired economic outcomes, e.g. higher wages and employment, increased value added, increased exports, while cluster efforts have an indirect impact on these outcomes through firm creation or increase in innovation rate.

According to Sölvell et al. (2003), the performance of CIs depends on its objectives, process by which cluster develops (e.g. governance, financing, scope of membership, resources, facilitators, framework, consensus) and the setting (e.g. business environment, government policy) in which they operate. By using CIs as platform, government may be interested in engaging in a strategic dialogue with the business community, in strengthening social capital in the region, in designing better policies and in attracting external funds available through EU programs. Through CIs membership, firms (particularly SMEs) may be interested in collaboration with other firms and academia and in improving the dialogue with the public (European Commission, 2013).

Cluster policy, as further important part of a cluster concept, includes a wider set of government policy interventions aiming at strengthening the competitiveness of existing clusters or facilitating the emergence of new ones (European Communities, 2008). Past research also indicates that every CI is unique and that there is no universal approach to their development, as setting, goals, process and performance vary among CIs. 


\section{Framework of competitiveness clusters in Croatia}

CCCs are non-profit associations that focus on sectors/industries of strategic importance for the development of the Republic of Croatia by linking private, scientific-research and public institutions (following Triple helix model) (MINGO, 2016). They are designed as an instrument for raising sectoral competitiveness and are promoted within a new form of industrial policy that promotes promising thematic domains rather than promising industries, under the condition of critical mass of entrepreneurs.

So far 13 CCCs have been established in the following domains of economic activity: automotive, wood-processing, food-processing industry, defence, chemical, electro and production machinery and technologies, ICT, maritime, construction, textile, health, personalized medicine, creative and cultural industries. Members of CCCs are companies from business sector, business clusters, professional organisations, and science and regional/local government. As defined in their Statutes, the main objectives of CCCs, along with strengthening the competitiveness of sectors, are the following: promoting networking and collaboration, greater usage of public and EU funds, attracting investments in the sector, lobbying for the sector at the national and the EU level, development of human resources and infrastructure, sector/industry brands' development and regional development (Statutes of CCCs, Croatian Agency for investment and competitiveness - AIK).

Those objectives should be fulfilled with various activities, including drafting and implementation of strategic plans of sector development, with efforts aimed at attracting new foreign direct investments in the sector, identification and implementation of strategic projects, lobbying government for regulatory and strategic framework for the sector at the national and the EU level and facilitating collaboration in Croatia and abroad (Statutes of CCCs, available at AIK website). Membership fees were not envisaged as a mechanism of financing. CCCs do not have employees, but AIK provides them with shared office spaces and equipment, as well with basic technical and administrative support on demand.

As CCCs are government initiated, public financing has so far been their primary source of funding. The funds allotted to CCCs in their first operative year were a lump-sum type of support that was sufficient only to cover their operative costs, and in the latter two years stronger public financial support was allocated based on a competitive procedure among CCCs. The procedure included evaluation of earlier CCC operations as well as evaluation of strategic relevance of CCC actions plans. This resulted in stronger differentiation among CCCs' performance. However, future government funding of CCCs appears uncertain. 


\section{Methodology}

The data for this study was obtained from on-line survey carried out among members of CCCs. Computer-Assisted Web Interviewing Method was used to collect the data during the period of March-July 2017. Target sample included 621 members of 13 CCCs, including 112 members of CCCs' governing boards. The list of representatives' names and addresses was obtained from AIK. To increase the response rate three reminders were sent out by e-mails. Professional interviewer was engaged to remind the representatives to fill-in the on-line survey. MINGO additionally reminded representatives of governing boards to take part in the survey. Finally, 279 questionnaires were completed. The response rate is at $44.9 \%$. After removing questionnaires with missing data and duplicates, we obtained a sample of 250 questionnaires that were used in the analysis. Sample characteristics are presented in Table 1.

The sample included members from business sector, business clusters, professional organisations and associations, academic and research organisations, and members from public sector. The majority of the sample included small and medium companies, mainly domestic companies (although there were also a few foreign companies) and companies that were founded after 1991. In the sample there were $42.7 \%$ of companies that experienced growth in employment and $55.0 \%$ of companies that had growth in revenues during the period of cluster operation, 2013-2016.

The questionnaire was designed based on interviews with experts and literature review (e.g. Sölvell et al., 2003; Lindqvist et al., 2013). It included items related to objectives, process, setting and CCCs' performance. Most questions were in the form of a statements, where respondents were asked to grade the extent to which they agreed, measured on a seven-degree Likert scale, ranging from 1 (disagree completely) to 7 (agree completely). The structure of the survey was based on the Cluster Initiative Performance Model (Sölvell et al., 2003). The data was analysed by using descriptive statistics, exploratory factor analysis and regression analysis. 


\section{Table 1.}

\section{SAMPLE CHARACTERISTICS}

\begin{tabular}{|c|c|c|}
\hline & $\mathbf{n}$ & $\%$ \\
\hline \multicolumn{3}{|l|}{ Type of CCC, $n=250$} \\
\hline CCC for automotive sector & 17 & 6.8 \\
\hline CCC for wood processing sector & 21 & 8.4 \\
\hline $\mathrm{CCC}$ for food processing sector & 26 & $\overline{10.4}$ \\
\hline $\mathrm{CCC}$ for creative and cultural industry & 31 & 12.4 \\
\hline CCC for chemical, plastics and rubber industry & 13 & 5.2 \\
\hline $\mathrm{CCC}$ for medical industry & 16 & 6.4 \\
\hline CCC for textile, leather goods and footwear industry & 17 & 6.8 \\
\hline CCC for construction industry & 8 & 3.2 \\
\hline CCC for ICT industry & 22 & 8.8 \\
\hline CCC for defence industry & 24 & 9.6 \\
\hline CCC for electrical and mechanical machinery industry and technology & 25 & 10.0 \\
\hline CCC for maritime industry & 20 & 8.0 \\
\hline CCC for personalised medicine & 10 & 4.0 \\
\hline \multicolumn{3}{|l|}{ Member type, $n=250$} \\
\hline Representatives of business sector & 131 & 52.4 \\
\hline Representatives of business clusters & 8 & 3.2 \\
\hline Representatives of professional organisations and associations & 25 & 10.0 \\
\hline Representatives of academic and research organisations & 44 & 17.6 \\
\hline Representatives of public sector & 42 & 16.8 \\
\hline Member in the governing board & 71 & 28.4 \\
\hline \multicolumn{3}{|l|}{ Year of joining the institution to $\mathrm{CCC}$} \\
\hline 2013 & 64 & 48.9 \\
\hline 2014-2017 & 65 & 49.6 \\
\hline \multicolumn{3}{|l|}{ Company size } \\
\hline Small companies & 66 & 50.4 \\
\hline Medium companies & 33 & 25.2 \\
\hline Large companies & 22 & 16.8 \\
\hline \multicolumn{3}{|l|}{ Age of company } \\
\hline $1872-1991$ & 45 & 34.4 \\
\hline $1992-2010$ & 63 & 48.1 \\
\hline $2011-2016$ & 15 & 11.5 \\
\hline \multicolumn{3}{|l|}{ Ownership of company } \\
\hline Domestic & 96 & 73.3 \\
\hline Mixed & 18 & 13.7 \\
\hline Foreign & 9 & 6.9 \\
\hline \multicolumn{3}{|l|}{ Changes in employment (2016/2013) } \\
\hline Decline & 40 & 30.5 \\
\hline No changes & 22 & 16.8 \\
\hline Growth & 56 & 42.7 \\
\hline \multicolumn{3}{|l|}{ Changes in revenues $(2016 / 2013)$} \\
\hline Decline & 43 & 32.8 \\
\hline No changes & 3 & 2.3 \\
\hline Growth & 72 & 55.0 \\
\hline
\end{tabular}

Source: Survey and authors' calculations. 


\section{Results}

\subsection{Objectives}

Objectives of CCCs are uniquely defined in their Statues and, given this approach; they are broadly defined and unquantified. A common understanding of CCCs' objectives among members is important as it may have influence on member's performance. In the survey, respondents were asked to rank the most important current objectives and results are given in table 2 .

Table 2.

OBJECTIVES DEFINED IN CCCS' STATUTES, N=250

\begin{tabular}{|l|c|c|}
\hline Objectives & n & \% \\
\hline Collaboration between public, private and science sectors. & 99 & 39.6 \\
\hline Enhancing competitiveness and increasing new added value in the sector. & 78 & 31.2 \\
\hline $\begin{array}{l}\text { Efficient usage of funds and obtaining aid and new sources of financing from } \\
\text { state budget and the EU. }\end{array}$ & 26 & 10.4 \\
\hline Lobbying for the sector at the national and the EU level. & 16 & 6.4 \\
\hline Attracting domestic and foreign investments in the sector. & 6 & 2.4 \\
\hline Development of human resources and their training. & 6 & 2.4 \\
\hline Development of business and research infrastructure. & 5 & 2.0 \\
\hline Collaboration among business sectors and internationalisation of the sector. & 5 & 2.0 \\
\hline Creating brands and promotion of the sector. & 4 & 1.6 \\
\hline Enhancing the attractiveness of regions and sustainable regional development. & 2 & 0.8 \\
\hline
\end{tabular}

Notes: Assess the following ten general objectives defined in the Statues of CCCs. Identify five most important objectives by ranking them from 1 to 5 , where 1 is the most important objective, and 5 the least important objective.

Source: Authors' calculations based on survey data.

As perceived by their members, highly ranked objectives are collaboration between public, private and science sectors and enhancing competitiveness and increasing new added value in the sector. Efficient usage of funds and obtaining aid and new sources of financing from state budget and the EU is also considered an important objective. All other objectives received little attention from respondents and can be considered as objectives of secondary importance. Low dispersion of perceived importance points to a shared understanding of these goals in the observed period. 
However, given the broad definition of these goals, respondents were also asked to identify the most important objectives that their CCCs should pursue in the future. Most highly regarded goals are related to innovation/technology and public support and policies, such as: promoting innovation and new technologies (87.6\% respondents agree), followed by facilitating higher innovativeness $(84.4 \%)$, improvement of regulatory policy (83.6\%), lobbying government for infrastructure (83.2\%), diffusion of technology within the sector (83.2\%), lobbying for subsidies (76.4\%) and studying and analysing the sector (72.8\%). Obviously, innovation and technology diffusion can be considered as a path towards reaching sectoral goals.

The survey also allowed for open comments, thus some additional input from respondents was received thanks to this option. Simplification of regulatory framework and improvement of business environment was given a lot of concern among respondents. Respondents find that CCCs can be the drivers of the development of the sector and think that CCCs should pursue more ambitious goals.

\subsection{Perceived performance of CCCs}

In this paper performance of CCCs was assessed as internal i.e. "organisational" performance and as external performance, through the effects of CCCs on companies in the sector during the period of 2013-2016. Members' perceptions of performance components are presented in Table 3.

Immediate impression is that there is general consensus among respondents on the fact that progress/performance of CCCs is not strongly visible. Majority of respondents strongly agree that $\mathrm{CCCs}$ did not provide benefits for cluster members (i.e. higher sales, employment, exports, innovations, process upgrading etc.), and it is these results that may also indicate some underperformance compared to expectations. This is particularly the case with the results that can be clearly quantified such as surge in FDI volume, development of new specializations, and growth of employment. Furthermore, when observing internal performance, roughly $60 \%$ of respondents agree that CCCs did not develop enough strength to be sustainable. In the light of curbing public financing, this is a rather unfavourable internal condition and should raise some concern among policy makers regarding the current CCC model. On the other hand, networking activity and promotional activities are more favourably ranked, although still negatively, as $38.4 \%$ and $25.6 \%$ of respondents agree that CCCs have led to closer industry-academia ties and have attracted new firms to the sector/industry, respectively. 
Table 3.

PERCEPTIONS OF CCCS’ PERFORMANCE, N=250, \%

\begin{tabular}{|l|r|r|r|}
\hline Performance items & \multicolumn{1}{|c|}{$\begin{array}{c}\text { Do not } \\
\text { agree (1) }\end{array}$} & $\begin{array}{c}\text { Indifferent } \\
\text { (2) }\end{array}$ & \multicolumn{1}{|c|}{$\begin{array}{c}\text { Agree } \\
\text { (3) }\end{array}$} \\
\hline $\begin{array}{l}\text { CCC has increased foreign direct investment (FDI) into the } \\
\text { sector. }\end{array}$ & 67.2 & 21.2 & 11.6 \\
\hline CCC helped the sector/industry develop new specialisations. & 63.6 & 23.6 & 12.8 \\
\hline CCC has led to increased employment in the sector. & 63.2 & 22.0 & 14.8 \\
\hline New technologies have emerged through CCC. & 62.4 & 22.0 & 15.6 \\
\hline CCC has led to product/process upgrading. & 62.0 & 24.8 & 13.2 \\
\hline $\begin{array}{l}\text { CCC has led to increased collaboration with international } \\
\text { companies within global value chains. }\end{array}$ & 60.8 & 21.2 & 18.0 \\
\hline CCC developed enough strength to be sustainable. & 60.0 & 19.2 & 20.8 \\
\hline CCC has helped the sector increase revenues. & 59.2 & 22.8 & 18.0 \\
\hline CCC promoted export of the sector/industry. & 56.4 & 24.0 & 19.6 \\
\hline CCC has improved international competitiveness of the sector. & 54.8 & 24.4 & 20.8 \\
\hline CCC has met its goals. & 52.8 & 21.6 & 25.6 \\
\hline CCC has attracted new firms to the sector/industry. & 51.2 & 23.2 & 25.6 \\
\hline CCC has led to closer industry-academia ties. & 40.8 & 20.8 & 38.4 \\
\hline
\end{tabular}

Note: Assess the performance of your CCC in the previous period. Do you agree with the following statements, where 1-disagree completely - 7 agree completely? Grouping of Likert scales was as follows: (1) do not agree $(1,2,3)$, indifferent $(4)$, agree $(5,6,7)$.

Source: Authors' calculations based on survey data.

Table 4 presents the distribution of members' perceptions with respect to perceived performance across CCCs. The results indicate that there are differences among members' perceptions with respect to CCCs (chi-square test, $\mathrm{p}<0.000$ ). Members in the sample more often positively evaluate CCCs for wood processing industry and for creative and cultural industries, and less favourably CCC for food processing sector.

The results have also shown that differences in perceived performance across different types of CCCs' members, representing business sector, business clusters, professional organisations and associations, academic and research organisations, and public sector institutions are not statistically significant (cross tabulation, Pearson chi-square: $8.497, \mathrm{df}=10, \mathrm{p}=0.580$ ). 
Table 4.

PERCEIVED PERFORMANCE ACROSS CCCS', N=250

\begin{tabular}{|l|r|r|r|}
\hline \multirow{2}{*}{ CCCs } & \multicolumn{3}{|c|}{ Perceived performance } \\
\cline { 2 - 4 } & \multicolumn{1}{|c|}{ Low } & \multicolumn{1}{|c|}{ Medium } & \multicolumn{1}{c|}{ High } \\
\hline CCC for defence industry & $18(10.06 \%)$ & $0(0 \%)$ & $6(10.17 \%)$ \\
\hline CCC for automotive sector & $10(5.59 \%)$ & $1(8.33 \%)$ & $6(10.17 \%)$ \\
\hline CCC for wood processing sector & $6(3.35 \%)$ & $1(8.33 \%)$ & $14(23.73 \%)$ \\
\hline CCC for food processing sector & $24(13.41 \%)$ & $1(8.33 \%)$ & $1(1.69 \%)$ \\
\hline CCC for chemical, plastics and rubber industry & $9(5.03 \%)$ & $3(25.00 \%)$ & $1(1.69 \%)$ \\
\hline CCC for maritime industry & $18(10.06 \%)$ & $0(0.00 \%)$ & $2(3.39 \%)$ \\
\hline CCC for creative and cultural industry & $21(11.73 \%)$ & $1(8.33 \%)$ & $9(15.25 \%)$ \\
\hline CCC for construction industry & $5(2.79 \%)$ & $0(0.00 \%)$ & $3(5.08 \%)$ \\
\hline CCC for medical industry & $13(7.26 \%)$ & $0(0.00 \%)$ & $3(5.08 \%)$ \\
\hline $\begin{array}{l}\text { CCC for electrical and mechanical machinery industry } \\
\text { and technology }\end{array}$ & $19(10.61 \%)$ & $2(16.67 \%)$ & $4(6.78 \%)$ \\
\hline CCC for ICT industry & $20(11.17 \%)$ & $1(8.33 \%)$ & $1(1.69 \%)$ \\
\hline CCC for textile, leather goods and footwear industry & $14(7.82 \%)$ & $0(0.00 \%)$ & $3(5.08 \%)$ \\
\hline CCC for personalised medicine & $2(1.12 \%)$ & $2(16.67 \%)$ & $6(10.17 \%)$ \\
\hline Total & $179(100 \%)$ & $12(100 \%)$ & $59(100 \%)$ \\
\hline
\end{tabular}

Notes: Perceived performance factor obtained from EFA was taken for the analysis of perceived performance across CCCs that was measured on a Likert scale from 1-7 (do not agree - agree). Responses from 1 to 3 were named as low performance, response 4 as medium performance, and responses from 5-7 as high performance.

Cross tabulation analysis: Pearson chi-square: $68.50, \mathrm{p}<0.000$.

Source: Survey and authors' calculations.

\subsection{Cluster process}

Cluster process includes the process by which CCs develop, i.e. the scope of membership, framework, governance, financing and operational activities. Members' perceptions on these issues are presented in table 5. More respondents agree than disagree that some effort was placed into designing the CCCs' model, that the vision of their CCCs was formulated and that there was an agreement on activities which should be carried out. However, objectives were not quantified enough and CCCs have been slow in implementation of major strategic documents. 


\section{Table 5.}

CLUSTER PROCESS, $\mathrm{N}=250, \%$

\begin{tabular}{|l|c|c|c|}
\hline & $\begin{array}{c}\text { Do not } \\
\text { agree (1) }\end{array}$ & $\begin{array}{c}\text { Indifferent } \\
\text { (2) }\end{array}$ & $\begin{array}{c}\text { Agree } \\
\text { (3) }\end{array}$ \\
\hline $\begin{array}{l}\text { Our CCC has sufficient budget for implementation of } \\
\text { important projects. }\end{array}$ & 78.4 & 14.4 & 7.2 \\
\hline $\begin{array}{l}\text { Our CCC shares its own experience with other CCs } \\
\text { within the same sector abroad. }\end{array}$ & 51.2 & 23.2 & 25.6 \\
\hline $\begin{array}{l}\text { Communication strategy for the sector/industry with } \\
\text { action plan is done and implemented. }\end{array}$ & 46.4 & 20.8 & 32.8 \\
\hline $\begin{array}{l}\text { Our CCC has its own working teams that deal with } \\
\text { specific topics/issues. }\end{array}$ & 46.4 & 23.2 & 30.4 \\
\hline $\begin{array}{l}\text { Our CCC shares its own experiences with other CCs } \\
\text { in the country. }\end{array}$ & 44.4 & 28.8 & 26.8 \\
\hline The objectives of CCC are quantified. & 42.8 & 23.6 & 33.6 \\
\hline $\begin{array}{l}\text { Strategic plan of sector development with goals, } \\
\text { priorities and action plan is done. }\end{array}$ & 38.4 & 24.0 & 37.6 \\
\hline $\begin{array}{l}\text { We invested a lot of effort and time in presentation of } \\
\text { our model of cooperation. }\end{array}$ & 34.8 & 22.8 & 42.4 \\
\hline $\begin{array}{l}\text { There is an agreement on which activities will be } \\
\text { carried out. }\end{array}$ & 32.4 & 22.8 & 44.8 \\
\hline The vision of CCC is formulated clearly. & 32.0 & 22.0 & 46.0 \\
\hline
\end{tabular}

Note: Assess cluster development process on the scale from 1 (disagree completely) to 7 (agree completely). Grouping of Likert scales was as follows: (1) do not agree $(1,2,3)$, indifferent (4), agree $(5,6,7)$.

Source: Survey and authors' calculations.

Regarding operational activities, CCCs again are not perceived well, as more respondents disagree than agree that their CCCs share their experiences and have established their own working teams to solve specific issues. The majority of respondents also found that CCCs do not have sufficient budget for implementation of important projects (78.4\%), and thus they need extra funding for projects. As pointed out, CCCs have received national funding for day-to-day work. While cooperation, networking and lobbying are affected by budget constraints to a lesser degree, some activities such as training, technology diffusion, promotion, infrastructure projects, expansion of firms require a higher budget. 


\subsection{Setting}

Two dimensions of setting, that have a particular effect on performance, are the quality of business environment and government policy. Findings from the survey are presented in table 6.

Table 6.

ASSESSMENT OF SETTING, N=250

\begin{tabular}{|l|c|c|r|}
\hline Setting items & $\begin{array}{c}\text { Do not } \\
\text { agree (1) }\end{array}$ & $\begin{array}{c}\text { Indifferent } \\
\text { (2) }\end{array}$ & $\begin{array}{c}\text { Agree } \\
\text { (3) }\end{array}$ \\
\hline Government policy is stable and predictable. & 79.6 & 10.8 & 9.6 \\
\hline Companies typically have trust in government initiatives. & 75.6 & 14.8 & 9.6 \\
\hline $\begin{array}{l}\text { Society is characterized by a high level of trust in business } \\
\text { relationships. }\end{array}$ & 73.2 & 16.8 & 10.0 \\
\hline Croatian government promotes science and innovation policy. & 63.6 & 16.8 & 19.6 \\
\hline $\begin{array}{l}\text { The sector/industry that your CCC serves is internationally } \\
\text { competitive. }\end{array}$ & 26.8 & 18.0 & 55.2 \\
\hline $\begin{array}{l}\text { The sector/industry that your CCC serves is characterized by } \\
\text { tight buyer-supplier networks. }\end{array}$ & 33.2 & 25.6 & 41.2 \\
\hline $\begin{array}{l}\text { The sector/industry that your CCC serves is comprised of } \\
\text { large numbers of companies. }\end{array}$ & 30.4 & 20.0 & 49.6 \\
\hline $\begin{array}{l}\text { The sector/industry that your CCC serves is characterized by } \\
\text { intense competition among companies. }\end{array}$ & 25.2 & 26.0 & 48.8 \\
\hline The sector/industry that your CCC serves has long history. & 24.8 & 10.8 & 64.4 \\
\hline
\end{tabular}

Note: Assess the business and economic setting in Croatia in which your CCC works. Do you agree with the following statements, where 1-disagree completely - 7 agree completely? Grouping of Likert scales was as follows: (1) do not agree $(1,2,3)$, indifferent $(4)$, agree $(5,6,7)$.

Source: Authors' calculations based on survey data.

The majority of respondents agree that the sectors their CCCs serve have long history. Fierce competition in sectors/industries prevails, accompanied by very low level of trust among companies. The results also show that recent changes with respect to employment and revenues in the sector have strong effect on perceptions of performance. As such, respondents coming from growing sectors are more likely to have more favourable perceptions of performance than respondents coming from stagnant or declining sectors (Chi square test, $\mathrm{p}=0.002$ ) 
Success of CCCs strongly depends on trust, which is a driver of cooperation among firms and innovations. As the findings suggest, firms are the least likely to trust each other in declining industries.

Findings of this survey also show that the majority of respondents had negative perceptions about current government policy and they predominantly do not trust government initiatives. This appears consistent with the findings from other transitional economies. A lack of government commitment and reduced national funding, and poor implementation of the program diminish trust in the longevity of government initiatives. Cluster program may, on the other hand, create expectations among cluster members that the role of government will solve their problems (European Communities, 2008).

\subsection{Factors of perceived performance}

\subsubsection{Assessment of reliability and construct validity}

Exploratory factor analysis (EFA) with Varimax rotation of factors was performed on 42 items related to cluster management process, setting-related items and perceived performance of CCCs. Principal component analysis was employed to extract the factors. The Kaiser-Guttman rule was used to determine the number of factors for extraction. The items that had low factor loading on respective factor, high factor loading on some other factor, and the items that cross-loaded on several factors were excluded from further analysis. The remaining 27 items were factor analysed again, and they loaded on five factors, as shown in Table 7. 


\section{Table 7.}

\section{RESULTS OF EXPLORATORY FACTOR ANALYSIS, N=250}

\begin{tabular}{|c|c|}
\hline Items, Cronbach's alpha coefficients $(\alpha)$ & $\begin{array}{l}\text { Factor } \\
\text { loadings }\end{array}$ \\
\hline \multicolumn{2}{|l|}{ Factor 1: Perceived performance; $\alpha=97$} \\
\hline CCC has improved international competitiveness of the sector. & 0.791 \\
\hline New technologies have emerged through CCC. & 0.793 \\
\hline CCC has helped the sector increase revenues. & 0.869 \\
\hline CCC has attracted new firms to the sector/industry. & 0.769 \\
\hline CCC has led to increased employment in the sector. & 0.890 \\
\hline CCC promoted export of the sector/industry. & 0.888 \\
\hline CCC has met its goals. & 0.648 \\
\hline CCC has led to increased collaboration with International companies within global value chains. & 0.779 \\
\hline CCC has increased FDI into the sector. & 0.844 \\
\hline CCC has led to product/process upgrading. & 0.818 \\
\hline CCC helped the sector/industry develop new specialisations. & 0.785 \\
\hline \multicolumn{2}{|l|}{ Factor 2: Strategy; $\alpha=0.93$} \\
\hline There is an agreement on which activities will be carried out. & 0.670 \\
\hline We invested a lot of effort and time in presentation of our model of cooperation. & 0.697 \\
\hline The vision of CCC is formulated clearly. & 0.714 \\
\hline The objectives of CCC are quantified. & 0.669 \\
\hline Strategic plan of sector development with goals, priorities and action plan is done. & 0.776 \\
\hline Communication strategy for the sector/industry with action plan is done and implemented. & 0.753 \\
\hline \multicolumn{2}{|l|}{ Factor 3: Government policy; $\alpha=0.86$} \\
\hline Croatian government promotes science and innovation policy. & 0.809 \\
\hline Government policy is stable and predictable. & 0.867 \\
\hline Companies typically have trust in government initiatives. & 0.832 \\
\hline \multicolumn{2}{|l|}{ Factor 4: Sector characteristics; $\alpha=\mathbf{0 . 8 6}$} \\
\hline The sector/industry that your CCC serves is internationally competitive. & 0.800 \\
\hline The sector/industry that your CCC serves is comprised of large numbers of companies. & 0.786 \\
\hline $\begin{array}{l}\text { The sector/industry that your CCC serves is characterized by intense competition among } \\
\text { companies in the cluster. }\end{array}$ & 0.847 \\
\hline The sector/industry that your CCC serves is characterized by tight buyer-supplier networks. & 0.769 \\
\hline \multicolumn{2}{|l|}{ Factor 5: Operational activities, $\alpha=0.83$} \\
\hline Our CCC has its own working teams that deal with specific topics/issues. & 0.695 \\
\hline Our CCC shares its own experiences with other CCs in the country. & 0.636 \\
\hline Our CCC shares its own experience with other CCs within the same sector abroad. & 0.739 \\
\hline
\end{tabular}

Source: Authors' calculations based on survey data. 
The reliability of scales was tested by Cronbach alpha coefficients, and they indicate adequate level of reliability. According to Nunnally and Bernstein (1994), Cronbach's alpha can be accepted with a value of 0.60 , while the value of 0.70 is regarded as the threshold. Table 8 presents Pearson correlations. Correlation coefficients are lower than 0.71, which is satisfactory according to MacKenzie, Podsakoff and Podsakoff (2011). These results suggest that both discriminant and convergent validity were confirmed through EFA approach. Obtained factors were used in regression analysis.

Table 8 .

\section{PEARSON CORRELATION COEFFICIENTS}

\begin{tabular}{|l|c|c|c|c|c|}
\hline \multicolumn{1}{|c|}{ Variables } & Factor 1 & Factor 2 & Factor 3 & Factor 4 & Factor 5 \\
\hline Factor 1 & 1.000 & & & & \\
\hline Factor 2 & 0.654 & 1.000 & & & \\
\hline Factor 3 & 0.418 & 0.420 & 1.000 & & \\
\hline Factor 4 & 0.333 & 0.469 & 0.308 & 1.000 & \\
\hline Factor 5 & 0.636 & 0.691 & 0.342 & 0.363 & 0.636 \\
\hline
\end{tabular}

Notes: $\mathrm{p}<.05$.

Source: Authors' calculations based on survey data.

\subsubsection{Regression analysis}

Multiple regression analysis was performed in order to statistically determine which factors influence perceived CCCs' performance. Perceived performance (Factor 1) was used as a dependent variable in the model, while independent variables in the model were strategy (Factor 2), government policy (Factor 3), sector characteristics (Factor 4), and operational activities of CCCs (Factor 5). All those factors represent strategic orientation, quality of cluster governance and management processes, and setting in which CCCs operate. Regression results are presented in table 9. The adjusted $\mathrm{R}^{2}$ is considered satisfactory at 0.503 . 
Table 9.

FACTORS INFLUENCING PERCEIVED PERFORMANCE, $\mathrm{N}=250$

\begin{tabular}{|l|c|c|c|c|}
\hline \multicolumn{1}{|c|}{ Independent variables } & $\begin{array}{c}\text { Standardized } \\
\text { regression } \\
\text { coefficients } \\
(\boldsymbol{\beta})\end{array}$ & $\begin{array}{c}\text { Unstandardized } \\
\text { coefficients } \\
(\mathbf{B})\end{array}$ & $\mathbf{t}(\mathbf{2 4 5})$ & p-level \\
\hline Factor 2: Strategy & 0.358 & 0.331 & 5.351 & 0.000 \\
\hline Factor 3: Government policy & 0.154 & 0.154 & 3.092 & 0.002 \\
\hline Factor 4: Sector characteristics & -0.005 & -0.004 & -0.089 & 0.929 \\
\hline Factor 5: Operational activities & 0.337 & 0.313 & 5.424 & 0.000 \\
\hline
\end{tabular}

Notes: $\mathrm{R}^{2}=0.511$, Adjusted $\mathrm{R}^{2}=0.503 ; \mathrm{F}(4,245)=64.054 ; \mathrm{p}<.000$; Std. Error of estimate: 0.94 .

Source: Authors' calculations based on survey data.

The results of regression analysis indicate that strategic orientation (including implementation of major strategic documents, formulation of vision and objectives) and operational activities of CCCs (including working teams and sharing experiences) are the most important factors that impact perceived performance, which is followed by government policy (including stability of policy, promotion and trust in policies). Sector characteristics were not shown to be significant.

Findings suggest that strategic issues and their implementation are very important in forming opinions about cluster results. CCCs that undertake more dynamic activity are more likely to assess the performance of their CCCs better than the others. Those CCCs are also in a better position to obtain public financing of their activities.

Results also indicate that the perception about government policy had an impact on perceived performance. This result is promising for policy-makers as it suggests that stability and predictability of government policy, improvements in policy framework and better promotion of science and innovation policy can further positively influence the opinions of possibilities to improve sectoral/industrial competitiveness among important actors from science, industry and regional/local government. 


\section{Comparison of Croatian competitiveness clusters with world's practice}

Comparison between Croatian CCs and similar associations in the world was made based on other surveys carried out in the world (Sölvell et al., 2003). Comparison of perceived performance is presented in table 10.

Table 10.

COMPARISON AMONG CLUSTER ASSOCIATIONS

\begin{tabular}{|c|c|}
\hline Similar associations in the world & Croatian CCs \\
\hline \multicolumn{2}{|l|}{ Perceived performance } \\
\hline $\mathrm{CI} / \mathrm{CCC}$ has met its goals $(81 \%)$. & CA: $25.6 \%$; CB: $36.6 \%$. \\
\hline CI/CCC developed enough strength to be sustainable (56\%). & CA: $20.9 \%$; CB: $24.0 \%$ \\
\hline CI/CCC has led to closer industry-academia ties (84\%). & CA: $38.4 \%$; CB: $47.9 \%$ \\
\hline New technologies have emerged through CI/CCC (58\%) & CA: $15.6 \%$; CB: $9.7 \%$ \\
\hline $\mathrm{CI} / \mathrm{CCC}$ has attracted new firms to the region $(60 \%)$ & CA:10.4\%; CB: $14.0 \%$ \\
\hline CI/CCC has led to increased employment in the sector. (59\%) & CA: $14.8 \%$. CB: $19.7 \%$ \\
\hline $\mathrm{CI} / \mathrm{CCC}$ has improved international competitiveness of the sector (66\%). & CA: $20.8 \%$; CB: $28.1 \%$ \\
\hline \multicolumn{2}{|l|}{ Process } \\
\hline The vision of $\mathrm{CI} / \mathrm{CCC}$ is formulated clearly (84\%). & CA: $46.0 \%$, CB: $55.0 \%$. \\
\hline The objectives of CI/CCC are quantified (68\%). & CA: $33.6 \%$; CB: $39.5 \%$ \\
\hline There is an agreement on which activities will be carried out $(83 \%)$. & CA: $44.8 \%$; CB: $56.3 \%$ \\
\hline $\begin{array}{l}\text { Our CCC has sufficient budget for implementation of important } \\
\text { projects }(25 \%) \text {. }\end{array}$ & CA: $7.2 \%$; CB: $7.0 \%$ \\
\hline \multicolumn{2}{|l|}{ Setting } \\
\hline Croatian government promotes science and innovation policy (76\%). & CA: $19.6 \% ; \mathrm{CB}=32.4 \%$ \\
\hline Government policy is stable and predictable (58\%). & CA: $9.6 \% ;$ CB: $21.1 \%$ \\
\hline Companies typically have trust in government initiatives (39\%). & CA: $9.6 \%$, CB: $29.6 \%$ \\
\hline $\begin{array}{l}\text { Society is characterized by a high level of trust in business } \\
\text { relationships }(58 \%) \text {. }\end{array}$ & CA: $10.0 \%$, CB: $28.2 \%$ \\
\hline $\begin{array}{l}\text { The sector/industry that your CI/CCC serves is internationally } \\
\text { competitive }(66 \%) \text {. }\end{array}$ & CA: $55.2 \%$; CB: $63.4 \%$ \\
\hline $\begin{array}{l}\text { The sector/industry that your CI/CCC serves is characterized by } \\
\text { intense competition among companies }(43 \%) \text {. }\end{array}$ & CA: $48.8 \%$; CB: $59.1 \%$ \\
\hline $\begin{array}{l}\text { The sector/industry that your CI/CCC serves is characterized by tight } \\
\text { buyer-supplier networks }(35 \%) \text {. }\end{array}$ & CA: $41.2 \%$; CB: $52.1 \%$ \\
\hline The sector/industry that your CI/CCC serves has long history (33\%). & CA: $64.4 \%$; CB: $71.8 \%$ \\
\hline
\end{tabular}

Notes: CA: Cluster assembly, CB: Cluster governing board. Percentage of affirmative answers ("agree") is given in brackets.

Sources: Global cluster Initiative Survey (Solvell et al., 2003); for Croatia: Authors' calculations based on survey data. 
It can be seen that Croatian respondents negatively evaluated the performance of their CCs as compared to respondents in other countries. Better perceived performance in the world can be explained by the fact that the Global cluster initiative survey was filled-in by cluster managers, and in Croatian survey, it was filled by both members of Governing board and Assembly (as there are no professional cluster managers in CCCs). Although, in Croatia, members of Governing boards assessed the performance of their clusters slightly better, the perceived performance of Croatian CCs still remains lower.

Worlds' surveys show that CIs that built a clear, explicit framework are more successful. In Croatia, there is a weak framework and consensus about objectives and activities, which negatively affect perceived performance. In Croatia, objectives of CCs are set broadly, while successful CIs rely more on growth-oriented goals, i.e. expansion of the sector, export growth, brand creation, higher innovativeness and diffusion of new technologies, education and training of workers, commercial cooperation.

Furthermore, in promoting competitiveness, CCs with offices and adequate budgets perform significantly better. In the world, on average, most of CIs have 3 or less employees, $87 \%$ of CIs have web page, $89 \%$ of CIs have cluster manager and 68\% of CIs have an office (Solvell et al., 2003; Lindquist, Ketels and Solvell, 2013), while in Croatia AIK provides resources for CCCs that are considered insufficient among cluster members, as this restricts them from pursuing more ambitious goals. On the other hand, in the world, most CIs rely on funding from a mix of financial sources. On average, $34 \%$ of world CIs revenues come from primarily private sources, such as membership fees and sales of services; about $54 \%$ come from public sources, mainly regional and local public funding; $12 \%$ come from other sources.

National public funding decreases with age, but this is compensated for an increase in the international public funding. Regional public funding remains rather constant. For private funding, a drop-in membership fees are compensated by a growth in sales of services. Younger CIs rely more on state national funding, while older CIs rely more on sale of services, international funding and membership fees (Lindquist et al., 2013).

As research shows, governance of successful CIs is more in the hands of private sector in the world. In Croatia, the share of private sector in Governing board is $34.8 \%$, while in the worlds' CIs its share is $61 \%$. Croatian CCCs are mostly structured of domestic companies, while the practice shows that CIs that are limited to domestic companies alone perform less efficiently. Successful CIs also undertake formal evaluation of their program. Finally, strong negative perceptions about government initiatives and a level of trust among companies further reduce the positive performance of CCs in Croatia. 


\section{Conclusion and discussion}

Croatian competitiveness clusters were established in 2013, and have been envisaged as an important instrument in the implementation of country's new Smart specialization strategy (2016) and in increasing sectoral competitiveness. The success of competitiveness clusters is still not confirmed in the literature, and, as public funding for CCCs has become questionable, they need to find new ways how to proceed in the future. This paper fills the gap in the literature and, based on perceptions of their members, assess the performance of CCCs, their processes and setting in which they operate, and examines the factors that contribute to performance of clusters.

The results show that CCC's members find that that progress/performance of their CCCs is not strongly visible, in particular, when quantifiable results are considered (e.g. growth of employment and FDI volume). An issue that should raise attention among policy makers in the light of curbing public financing for CCCs is that roughly $60 \%$ of respondents find that CCCs did not develop enough strength to be sustainable.

There are several factors that negatively affect perceived performance of CCCs, and the most important ones are weaknesses inherited in cluster development framework, poor implementation of activities, inadequate resources for pursuing more ambitious objectives, lack of consensus and weaknesses in strategy formulation. Findings also show that Croatian CCs are lagging behind successful CIs in the world in their performance as they do not have a stable source of financing, professional managers and adequate resources to pursue more ambitious goals and activities.

The results show that internal factors (such as strategic orientation and operational activities of CCCs) are the most important drivers of perceived performance and are more important than environmental factors (such as government policy). In order to strengthen existing CCCs, changes in the national framework are needed (e.g. some clusters can be combined and CCCs might become legal entities). Practices and experiences of similar international associations can be very useful in designing more effective development framework in Croatia.

For CCCs to be able to perform more ambitious goals and activities, it is important that they hire experienced cluster managers/facilitators, and have at their disposal offices and an adequate budget. CCCs should rely less on the state budget and should find new sources of financing. In particular, membership fee increases members' commitment to cluster activities, which, however, implies changes in legal status of CCCs. Internationalisation of CCCs should be supported as well. For example, cluster organisations are a front door for clusters to join international 
networks and global value chains (European Communities, 2008), and in Croatian case, CCCs could play the same role for sectors and industries. Regular assessment of CCCs' performance is next recommendation to be drawn from worldwide cluster organisations and policy makers' practice (European cluster Excellence Initiative).

This study also has some limitations. One limitation may come from using the subjective methodology which is appropriate for an early evaluation of the exploratory type, but its shortcoming may be seen in the case when respondents have an interest in overstating the effects, as they may expect further public financing of CCCs.

Future research can be directed towards examining differences among perceived performance across different characteristics of members (e.g. company size, age, and ownership). Another avenue of research can be seen in researching the impact of the implemented government funding scheme applicable for CCs, as well as in gaining additional insight about the internal relationships, particularly between large and small companies as well between the academia representatives and business community. Furthermore, the interdependencies among future objectives, performance, cluster management and governance processes can be analysed in more depth.

Acknowledgments: Draft version of the paper was presented during Training Workshop named 'Training Workshop on Cluster Evolution' held from 6 to 8 September in Milano 2017, within the project "Strengthening scientific and research capacity of the Institute of Economics, Zagreb as a cornerstone for Croatian socioeconomic growth through the implementation of Smart Specialisation Strategy" (H2020-TWINN-2015-692191-SmartEIZ).

\section{References:}

Agency for Investments and competitiveness (AIK). Competitiveness clusters. Available at http://www.aik-invest.hr/en/competitiveness/competitiveness-clusters/

Boschma, R. (2016). Smart Specialisation and Regional Innovation Policy. Welsh Economic Review, 24, 17. DOI: 10.18573/j.2016.10050.

European cluster Excellence Initiative (ECEI). The quality label for cluster organisations - criteria, processes, framework of implementation. Available at http://www.clusterpolisees3.eu/ClusterpoliSEEPortal/resources/cms/documents/2012.05.22_The_ quality_label_and_indicators_for_cluster_organisations_assessment.pdf

European Communities (2008). The Concept of Clusters and Cluster Policies And Their Role For Competitiveness And Innovation: Main Statistical Results and Lessons Learned. Luxembourg: Office for Official Publications of the European 
Communities. Available at file://C:/Users/danic/Downloads/2008.2494_deliverable_EN_web\%20(1).pdf

European Commission (2013). The Role of Clusters in Smart Specialisation Strategies. Luxembourg: Publications Office of the European Union. Available at https:// ec.europa.eu/research/evaluations/pdf/archive/other_reports_studies_and_documents/clusters_smart_spec2013.pdf

Kowalski, A. M., \& Marcinkowski, A. (2014). Clusters versus Cluster Initiatives, with Focus on the ICT Sector in Poland. European Planning Studies, 22(1), 20-45. DOI: 10.1080/09654313.2012.731040.

Lindqvist, G., Ketels, C., \& Sölvell, Ö. (2013). The Cluster Initiative Greenbook 2.0. Stockholm: Ivory Tower.

MacKenzie, S., Podsakoff, P., \& Podsakoff, N. (2011). Construct Measurement and Validation Procedures in MIS and Behavioural Research: Integrating New and Existing Techniques. MIS Quarterly, 35(2), 293-334. DOI: 10.2307/23044045.

Maffioli, A., Pietrobelli, C., \& Stucchi, R. (Eds.) (2016). The Impact Evaluation of Cluster Development Programs Methods and Practices. New York: Inter-American Development Bank.

Ministry of Economy, entrepreneurship and crafts (MINGO) (2016). Croatian Smart Specialisation Strategy 2016-2020. Available at http://s3platform.jrc.ec.europa.eu/ documents/20182/222782/strategy_EN.pdf/e0e7a3d7-a3b9-4240-a651-a3f6bfaaf10e

Nunnally, J. C., \& Bernstein, I.H. (1994). Psychometric theory. New York: McGraw-Hill, Inc.

OECD (2013). Innovation-driven Growth in Regions: The Role of Smart Specialisation. Paris: OECD Publications. Available at https://www.oecd.org/innovation/inno/ smart-specialisation.pdf

Porter, M. (2003). The economic performance of regions. Regional Studies, 37(6-7), 549578. DOI: $10.1080 / 0034340032000108688$.

Radas, S., \& Anić, I.-D. (2013). Evaluating additionality of an innovation subsidy program targeted at SMEs: an exploratory study. Croatian economic survey, 15(1), 61-88.

Sölvell Ö., Lindqvist, G., \& Ketels C. (2003). The Cluster Initiative Greenbook. Stockholm: Ivory Tower.

Zekić, Z., \& Samaržija, L. (2017). Analysis of the impact of selected supply chain management factors on the performance of wood industry clusters in the Republic of Croatia. Ekonomski pregled, 68(1), 59-87. 


\title{
KLASTERI KONKURENTNOSTI U HRVATSKOJ
}

\author{
Sažetak
}

Rad istražuje percepcije članova 13 klastera konkurentnosti u Hrvatskoj o ciljevima, procesima, okruženju i učincima klastera. Podaci iz uzorka $(n=250)$ analizirani su metodama deskriptivne statistike, eksplorativnom faktorskom analizom i regresijom. Rezultati pokazuju da napredak klastera konkurentnosti nije dovoljno vidljiv u promatranom razdoblju i da klasteri konkurentnosti zaostaju za uspješnim klasterima u svijetu. Među čimbenicima koji objašnjavaju nepovoljne rezultate su neodgovarajući modeli razvoja klastera, neučinkovita implementacija aktivnosti, nedostatak konsenzusa i nedostaci u formuliranim strategijama. Ovo istraživanje pridonosi literaturi tako što analizira program klastera konkurentnosti po prvi puta. Jednako tako, istraživanje istražuje čimbenike koji pridonose rezultatima klastera i uspoređuje prakse klastera konkurentnosti u Hrvatskoj s najboljom praksom sličnih asocijacija u svijetu. Iako se ovo istraživanje temelji na percepcijama članova, ono ima značajne implikacije za klastere i nositelje politike. Da bi ojačali postojeći klasteri, potrebne su promjene u nacionalnom sustavu, dok bi klasteri morali imati više resursa na raspolaganju kako bi u budućnosti ostvarivali ambicioznije ciljeve.

Ključne riječi: strategija pametne specijalizacije, program klastera konkurentnosti, klasteri konkurentnosti, anketno istraživanje, percepcije, rana evaluacija. 